\title{
Artificial drying of safflower seeds at different air temperatures: effect on the physiological potential of freshly harvested and stored seeds ${ }^{1}$
}

\author{
Guilherme Cardoso Oba ${ }^{2 *}$ (iD, André Luís Duarte Goneli² (iD, \\ Tathiana Elisa Masetto ${ }^{2}$ (D), Cesar Pedro Hartmann-Filho² (iD), \\ Karina Laís Leite Sarath Michels ${ }^{2}$ (D), João Paulo Correia Ávila ${ }^{2}$
}

\begin{abstract}
The air temperature used in the drying process can determine the initial physiological quality and storage potential of a seed lot, which is the object of this study. Safflower seeds, harvested at a moisture content of $25.8 \%$, were subjected to drying in an experimental dryer at air temperatures of $40,50,60$ and $70{ }^{\circ} \mathrm{C}$ until reaching a moisture content of 6.6 $\pm 0.6 \%$. Immediately upon drying and every 60 days after that, up to 240 days of storage under uncontrolled conditions, seed samples were collected to determine physiological quality. Increasing drying air temperature resulted in higher water removal rates, promoting immediate and latent damage to seed physiological quality, evidenced by the reduction in the percentage and speed of root protrusion, first count, and germination, mainly at temperatures of 60 and $70{ }^{\circ} \mathrm{C}$. For the maintenance of safflower seed germination and vigor up to 240 days of storage, it is recommended that drying air temperature does not exceed $40{ }^{\circ} \mathrm{C}$, especially when seeds present moisture contents close to or higher than $25.8 \%$ at the drying moment.
\end{abstract}

Index terms: Carthamus tinctorius L., drying damage, germination potential.

\section{Secagem artificial de sementes de cártamo em diferentes temperaturas do ar: efeito no potencial fisiológico das sementes recém-colhidas e armazenadas}

\begin{abstract}
RESUMO - A temperatura do ar empregado no processo de secagem pode determinar a qualidade fisiológica inicial e o potencial de armazenamento de um lote de sementes, sendo esse o objeto de estudo desta pesquisa. Sementes de cártamo, colhidas com teor de água de $25,8 \%$, foram submetidas à secagem em secador experimental às temperaturas do ar de $40,50,60 \mathrm{e} 70{ }^{\circ} \mathrm{C}$, até atingirem grau de umidade de $6,6 \pm 0,6 \%$. De imediato à secagem e a cada 60 dias subsequentes, até 240 dias de armazenamento sob condições não controladas, foram coletadas amostras de sementes para a determinação da qualidade fisiológica. O aumento da temperatura do ar de secagem resultou em maiores taxas de remoção de água, promovendo danos imediatos e latentes à qualidade fisiológica das sementes, evidenciados pela redução da porcentagem e velocidade da protrusão radicular, primeira contagem e germinação, sobretudo com as temperaturas de 60 e $70^{\circ} \mathrm{C}$. Para a manutenção da germinação e vigor das sementes de cártamo até os 240 dias de armazenamento, recomenda-se que a temperatura do ar de secagem não exceda a $40{ }^{\circ} \mathrm{C}$, especialmente quando essas se apresentarem com teores de água próximos ou superiores a $25,8 \%$ no momento da secagem.
\end{abstract}

Termos para indexação: Carthamus tinctorius L., danos de secagem, potencial de germinação.

\section{Introduction}

Safflower (Carthamus tinctorius L.), a species belonging to the Asteraceae family, is an annual herbaceous plant adapted for cultivation under semi-arid conditions (Flemmer et al., 2015). It is recognized for its medicinal (Zhou et al.,
2014) and dye properties (Laursen and Mouri, 2013), as well as for its use in supplementary poultry and ruminant feeding (Emongor, 2010) and its possible use as a winter crop in rotation systems (Souza et al., 2016).

Its seeds, botanically called achenes, have considerable protein (14.7 to $16.2 \%$ ) and lipid (23 to $41 \%$ ) contents,

\footnotetext{
${ }^{1}$ Submitted on 5/4/2018. Accepted for publication on 9/5/2019.

${ }^{2}$ Universidade Federal da Grande Dourados, Faculdade de Ciências Agrárias, Caixa Postal 533, 79804-970 - Dourados, MS, Brasil.

*Corresponding author <guilherme_oba@hotmail.com>
} 
standing out the content of linoleic (71.6 to 83.7\%) and oleic (7.5 to $18.4 \%$ ) acids in its oil, giving it high herbal, nutritional, and commercial value (Al Surmi et al., 2016; Khalid et al., 2017). Although it has greater importance for human nutrition, safflower oil also has satisfactory characteristics for biodiesel production (Oliveira et al., 2018). Despite the relevance, studies on the production chain of safflower seed are still scarce, especially those related to postharvest stages.

Safflower seeds reach physiological maturity with moisture contents ranging from 47 to $29 \%$, according to genotype and edaphoclimatic cultivation conditions (Franchini et al., 2014). However, harvesting is usually performed after the senescence of parent plants, when seeds are already with moisture contents close to 13\% (Flemmer et al., 2015). Also, to maintain physiological quality until sowing in the following season, it is recommended that the moisture content of these seeds does not exceed $8 \%$ during storage (Desai, 2004).

In general, orthodox seeds stored with high moisture content, safety limits according to species and water activity in the product, are subject to a rapid increase in respiratory and metabolic activity, promoting accelerated consumption of reserve substances, resulting in premature loss of germination and vigor potential. Moreover, the increased intergranular moisture and air temperature, caused by an increase in seed respiratory rate, favors the increased activity of microorganisms and insects in the mass, also contributing to the acceleration of the deterioration of the stored product (Barrozo et al., 2014). In this sense, when harvested with moisture contents higher than $8 \%$, mainly at early harvests, closer to physiological maturity, it is essential to dry safflower seeds as soon as possible before storing them (Desai, 2004).

Drying by forced convection of heated air is a simultaneous process of heat and mass transfer, determined by the phenomenon of the partial vapor pressure difference between the surface of the material to be dried and the surrounding air (Keneni et al., 2019). In addition to reducing seed water content up to safe levels for storage, artificial drying also has the advantage of early harvesting, minimizing quantitative and qualitative losses in the field by different natures (Scariot et al., 2018).

According to Barrozo et al. (2014), optimal drying preserves the viability, vigor, and physical integrity of seeds, associated with higher energy and operational efficiency. However, according to the authors, conditions that promote high drying rates (e.g., high temperature and/or low relative air humidity) can cause severe physical and physiological damage to seeds, especially when they are at very high degrees of moisture.

High drying temperatures usually lead to overheating and abrupt removal of water molecules contained inside the seeds. These deleterious events are sufficient to cause crack formation in internal and external tissues (Menezes et al., 2012), protein body coalescence and oil droplet disruption (Donadon et al., 2013), disorganization of tegument and embryo cell structures associated with cell content leakage (Saath et al., 2010; Borém et al., 2013; Wang et al., 2017), and the consequent loss of initial physiological quality and seed storage potential (Resende et al., 2012; Ullmann et al., 2015; Hartmann-Filho et al., 2016; Sarath et al., 2016; Timple and Hay, 2018).

Considering the need for information on postharvest management of safflower crop, especially those related to drying, this study aimed to evaluate the immediate and latent effects of different drying air temperatures on the physiological quality of safflower seeds.

\section{Material and Methods}

\section{Collection of biological material and sample preparation}

The experiment was conducted at the Laboratory of Preprocessing and Storage of Agricultural Products and Laboratory of Oilseed Grain Quality of the Universidade Federal da Grande Dourados (UFGD), Dourados, MS, Brazil. Safflower seeds produced at the Experimental Farm of Agricultural Sciences of UFGD (geographical coordinates of $22^{\circ} 14^{\prime} \mathrm{S}$ and $54^{\circ} 59^{\prime} \mathrm{W}$, and altitude of $434 \mathrm{~m}$ ), with all necessary crop management, were used.

Safflower heads were manually harvested in a period close to the physiological maturity point, characterized by the presence of heads with at least $70 \%$ of the area of senescent bracts (Franchini et al., 2014; Flemmer et al., 2015), when seeds had a moisture content of $25.8 \%$.

\section{Seed drying and storage}

After manual threshing and processing, seeds were dried in a fixed bed experimental dryer under continuous supply of heated air at $40,50,60$ and $70{ }^{\circ} \mathrm{C}$ and airflow of $0.2 \mathrm{~m}^{3} \cdot \mathrm{s}^{-1} \cdot \mathrm{m}^{-2}$ until reaching a moisture content of $6.6 \pm 0.6 \%$, as indicated for the storage of seeds from this species (Desai, 2004).

The reduction of seed moisture content during drying was verified by the gravimetric method (mass loss). Thus, the water removal rate of the material was determined for different drying air conditions by Equation 1, which refers to the amount of water that a given product loses per unit of dry matter per unit time (Corrêa et al., 2001).

$$
\mathrm{WRR}=\frac{\mathrm{Wm}_{0}-\mathrm{Wm}_{\mathrm{i}}}{\mathrm{DM}\left(\mathrm{t}_{\mathrm{i}}-\mathrm{t}_{0}\right)}
$$

where WRR is the water removal rate $\left(\mathrm{kg}^{\mathrm{kg}} \mathrm{kg}^{-1} \cdot \mathrm{h}^{-1}\right), \mathrm{Wm}_{0}$ is 
the total previous water mass $(\mathrm{kg}), \mathrm{Wm}_{\mathrm{i}}$ is the total current water mass $(\mathrm{kg}), \mathrm{DM}$ is the dry matter mass $(\mathrm{kg}), \mathrm{t}_{0}$ is the total previous drying time (h), and $\mathrm{t}_{\mathrm{i}}$ is the total current drying time (h).

The initial and final moisture contents were determined by the oven method at $105 \pm 1{ }^{\circ} \mathrm{C}$ for 24 hours in triplicate, according to the Rules for Seed Testing (RST) (Brasil, 2009).

After drying, the seeds were placed in non-airtight, rigid plastic containers, simulating the bulk stock system. Then, they were stored for 240 days under uncontrolled temperature and relative air humidity $(\mathrm{RH})$ conditions, protected from light and precipitation. Temperature and $\mathrm{RH}$ variation of the storage environment was recorded daily using two thermo hygrometers installed close to the containers with the seeds.

Immediately after drying and up to 240 days after the beginning of storage, at 60-day intervals, moisture content (Brasil, 2009) and the immediate and latent effects of different drying air temperatures on seed physiological quality were determined.

\section{Evaluation of seed physiological quality}

Before the physiological tests, seeds were preconditioned in mini-chambers (gerbox) at $25{ }^{\circ} \mathrm{C}$ and $100 \% \mathrm{RH}$ for 24 hours to avoid damage by soaking in water. Subsequently, disinfestation was performed by immersion in $2.5 \%$ sodium hypochlorite solution for five minutes, followed by rinsing under running water.

Preliminary analyses showed physiological dormancy in safflower seeds, as observed in studies by Dolatabadian and Sanavy (2008) and Mayerhofer et al. (2011). This characteristic could provide doubtful results on the immediate and latent effects of drying treatments on the physiological quality of seeds. In this sense, the inclusion of a third treatment factor was necessary for this study, related to the use or not of the cold stratification method to overcome dormancy of freshly harvested or stored seeds.

The collected samples from each drying treatment were subdivided at each storage period into two equivalent portions, one of which directly submitted to the germination test. The other portion was previously subjected to the cold stratification method in a substrate moistened with distilled water at $10{ }^{\circ} \mathrm{C}$ for five days in the dark (Oba et al., 2017), aiming to overcome seed dormancy. After this period, seeds were submitted to the germination test.

The germination test was conducted according to RSA (Brasil, 2009), using paper substrates consisting of three sheets of germination paper previously moistened with distilled water volumes corresponding to 2.5 times the dry paper weight with four replications of 50 seeds each one. Substrates with seeds were maintained in a Mangelsdorf germination chamber at $25^{\circ} \mathrm{C}$ under constant white light for 14 days.

The percentage of root protrusion (minimum $1 \mathrm{~mm}$ ) was determined on the $14^{\text {th }}$ day of the test, while the percentages of normal seedlings at first count and germination were recorded on the fourth and $14^{\text {th }}$ day, respectively. At the same time, the root protrusion speed index (Maguire, 1962) was determined by daily counting the number of seeds with a minimum root protrusion of $1 \mathrm{~mm}$ from the first to the $14^{\text {th }}$ day of the germination test.

\section{Statistical procedure}

The experiment was conducted in a completely randomized design in a split-plot scheme. Plots consisted of drying air temperatures $\left(40,50,60\right.$ and $\left.70{ }^{\circ} \mathrm{C}\right)$, subplots consisted of storage periods $(0,60,120,180$ and 240 days), and sub-subplots were represented by the use of cold stratification (with and without stratification). Data on germination and seed vigor were subjected to analysis of variance using the statistical program SISVAR (Ferreira, 2011).

For comparison purposes, the results of non-stratified and cold stratified seeds at each drying treatment level and storage period were submitted to the Tukey test at $5 \%$ probability. Subsequently, storage periods within each drying temperature level were sliced by regression analysis, separately for nonstratified and stratified seeds. Models were selected based on the values of the coefficient of determination $\left(R^{2}\right)$, the significance level of the equation ( $\mathrm{p}$-value), and knowledge of the biological phenomenon under study.

\section{Results and Discussion}

Drying periods required for seeds to reach a moisture content of $6.6 \pm 0.6 \%$ at $40,50,60$ and $70{ }^{\circ} \mathrm{C}$ were 3.83 , $2.22,1.50$ and 1.08 hours, respectively, with the highest water removal rates (WRR) occurring at the highest drying temperatures $\left(70\right.$ and $\left.60{ }^{\circ} \mathrm{C}\right)$, especially at the beginning of the process (Figure 1). The higher the drying temperature is, the greater the difference in vapor partial pressure between the surface of the material to be dried and surrounding air, which results in faster removal of water molecules from the product in the form of vapor (Keneni et al., 2019). Consequently, this phenomenon leads to a reduction in drying time, as observed in the present study (Figure 1).

A considerable variation in ambient air temperature and $\mathrm{RH}$ was observed over the 240 days of the experimental period because seed storage was conducted under uncontrolled conditions (Figure 2). During this period, mean, maximum, and minimum values of temperature of $24.7 \pm 2.7,30.2$ and $18.5^{\circ} \mathrm{C}$ and $\mathrm{RH}$ of $59.4 \pm$ $10.3,82.0$ and $37.0 \%$, respectively, were recorded. 


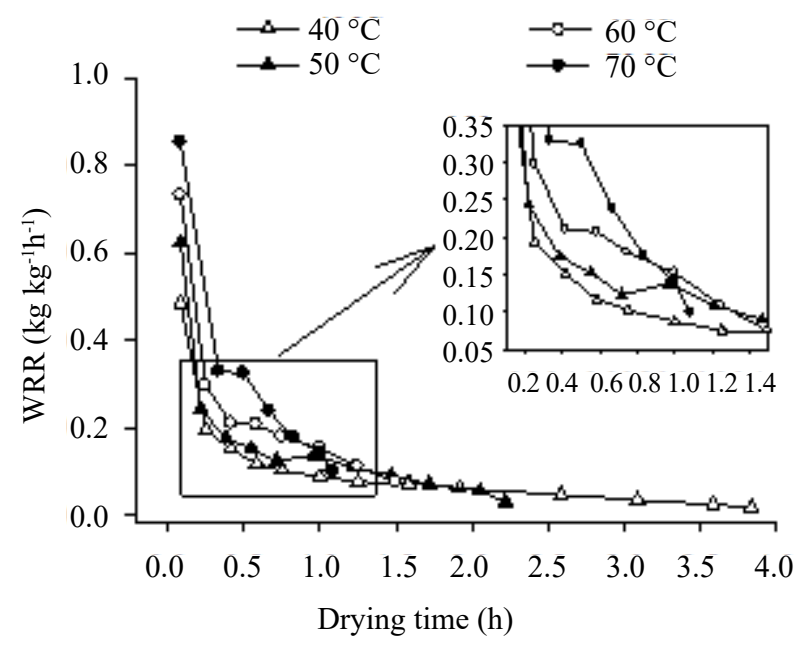

Figure 1. Water removal rate for safflower seeds dried at different air temperatures.

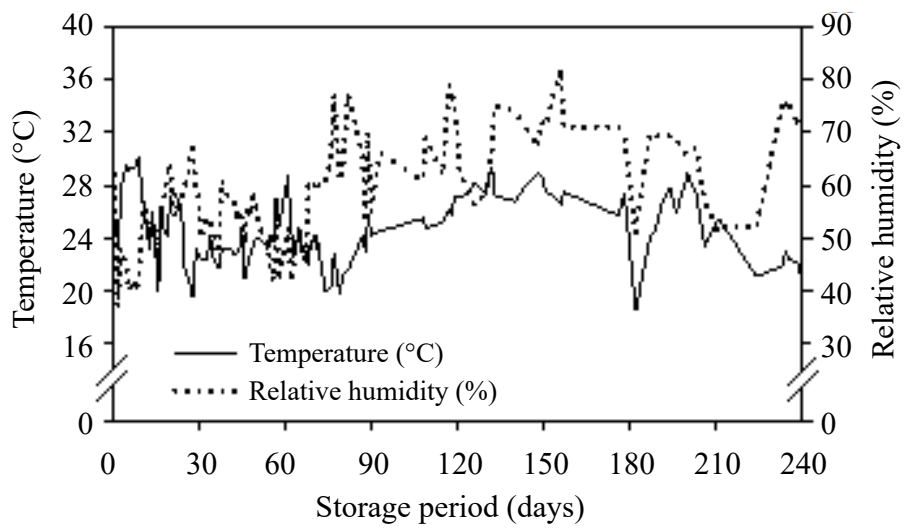

Figure 2. Data of temperature and mean relative air humidity of safflower seed storage environment. Dourados, MS.

Seeds, such as those of safflower, are subject to variation in moisture content due to hygroscopicity, according to oscillations in surrounding air properties (Barati et al., 2016), especially when packaged in a non-gas-resistant packaging (Scariot et al., 2018). In this study, seeds were packaged in non-airtight containers and stored under uncontrolled temperature and relative air humidity conditions (Figure 2). The interaction between these factors allowed an increase in seed moisture content during storage due to the gradual adsorption of ambient air water molecules, regardless of the initial drying treatment (data not shown). At the end of 240 days, the mean moisture content was $8.4 \pm 0.4 \%$, higher than the initial mean moisture content $(6.6 \pm 0.6 \%)$.

Table 1 shows a significant interaction between factors drying air temperature, storage period, and cold stratification $(p<0.01)$ for all physiological characteristics.

The effect of cold stratification treatment (without and with) within each drying temperature level $\mathrm{x}$ storage period is shown in Table 2. Regardless of the initial drying conditions, the use of stratification promoted a significant increase in root protrusion and germination of freshly harvested or stored seeds up to 120 days. From 180 days of storage, except for root protrusion of seeds dried at $40{ }^{\circ} \mathrm{C}$ and stored for 240 days and seed germination of treatments $40{ }^{\circ} \mathrm{C} / 180$ days and $40{ }^{\circ} \mathrm{C} / 240$ days, in which higher values were verified for stratified seeds, no significant differences were found between stratification and non-stratification of seeds. Regarding root protrusion speed index (RPSI) and first count, the positive effects of stratification on the results were observed until 240 days of storage, except for seeds from drying at $70{ }^{\circ} \mathrm{C}$, which presented statistically equal values when subjected or not to stratification at 180 and 240 days only.

These results confirmed the presence of physiological dormancy in safflower seeds, which was predominant in the first 120 days of storage, and effectiveness of cold stratification in the immediate overcoming of dormancy and consequent increase in the speed of the germination process (Table 2). Therefore, the use of cold stratification to access the 
Table 1. Summary of the analysis of variance for the characteristics root protrusion (RP), root protrusion speed index (RPSI), first count (FC), and germination (G) of safflower seeds as a function of drying air temperature, storage period, and cold stratification.

\begin{tabular}{|c|c|c|c|c|c|}
\hline \multirow{2}{*}{ SV } & \multirow{2}{*}{$\mathrm{DF}$} & \multicolumn{4}{|c|}{ Calculated F } \\
\hline & & $\mathrm{RP}$ & RPSI & FC & G \\
\hline Drying temperature (DT) & 3 & $1273.8^{* *}$ & $2227.9^{* *}$ & $542.0^{* *}$ & $493.2 * *$ \\
\hline Residual (a) & 12 & - & - & - & - \\
\hline Storage period (SP) & 4 & $48.0^{* *}$ & $81.3^{* *}$ & $77.8^{* *}$ & $4.5^{* *}$ \\
\hline Interaction DT x SP & 12 & $27.0^{* *}$ & $12.1^{* *}$ & $5.9^{* *}$ & $9.7^{* *}$ \\
\hline Residual (b) & 60 & - & - & - & - \\
\hline Cold stratification (CS) & 1 & $1172.1^{* *}$ & $7020.0^{* *}$ & $3490.4^{* *}$ & $1267.8^{* *}$ \\
\hline Interaction DT x CS & 3 & $86.8^{* *}$ & $1027.8^{* *}$ & $466.9^{* *}$ & $122.3^{* *}$ \\
\hline Interaction SP x CS & 4 & $197.5^{* *}$ & $288.3^{* *}$ & $89.5^{* *}$ & $165.1^{* *}$ \\
\hline Interaction DT x SP x CS & 12 & $12.8^{* *}$ & $23.8^{* *}$ & $7.0^{* *}$ & $13.7^{* *}$ \\
\hline Residual (c) & 48 & - & - & - & - \\
\hline Total corrected & 159 & - & - & - & - \\
\hline CV $1(\%)$ & - & 11.1 & 10.2 & 19.9 & 20.0 \\
\hline CV $2(\%)$ & - & 10.5 & 10.2 & 21.3 & 17.3 \\
\hline CV $3(\%)$ & - & 12.1 & 11.4 & 20.8 & 14.5 \\
\hline Overall mean & - & 44.3 & 12.9 & 19.7 & 33.4 \\
\hline
\end{tabular}

**Significant at $1 \%$ probability of error by the F-test.

SV: sources of variation.

DF: degrees of freedom.

$\mathrm{CV}$ : coefficient of variation.

real physiological potential of seeds considering immediate and latent effects of drying treatments is justified in this study.

Immediate effects of drying temperatures on root protrusion and RPSI was not differentiated for seeds not subjected to cold stratification, showing mean values of $6 \pm$ $2 \%$ (Figure 3A) and $0.43 \pm 0.15$ (Figure 3B), respectively, at 0 days of storage. However, the natural and gradual overcoming of seed dormancy in the subsequent storage periods led to higher values of both characteristics for seeds dried at 40 and $50{ }^{\circ} \mathrm{C}$ (which showed similar behavior) in relation to those presented by lots dried at 60 and $70{ }^{\circ} \mathrm{C}$, especially from 120 days. Root protrusion and RPSI of seeds dried at 40, 50 and $60{ }^{\circ} \mathrm{C}$ were represented by first-degree polynomial models, with no regression adjustment for the lot dried at $70^{\circ} \mathrm{C}$.

When the effect of physiological dormancy was suppressed by cold stratification, the application of temperatures of $60^{\circ} \mathrm{C}$ and mainly $70^{\circ} \mathrm{C}$ provided a drastic and immediate reduction of root protrusion (Figure 3C) and RPSI (Figure 3D) of seeds, persisting low values in the subsequent periods of storage. The best results when using stratification were observed in the lot dried at $40{ }^{\circ} \mathrm{C}$, which maintained high percentages of root protrusion ( $96 \%$ on average) and RPSI values $(46.0 \pm 0.8)$ up to 120 days of storage, gradually decreasing in the subsequent periods (Figures $3 \mathrm{C}$ and 3D). Seeds dried at $50{ }^{\circ} \mathrm{C}$ showed a more pronounced decrease in root protrusion and, especially, RPSI during storage when compared to the lot subjected to drying at $40{ }^{\circ} \mathrm{C}$, showing that a $10^{\circ} \mathrm{C}$ increase in drying temperature was sufficient to provide latent damage, mainly in aspects related to seed vigor.

In the stationary drying method under a continuous supply of heated air, as used in this study, seeds tend to reach temperatures very close to those of the drying air (Barrozo et al., 2014). Thus, the higher the air temperature used in the process is, the higher the risks of disorganization and disruption of various cell structures, leakage of cytoplasmic content, and formation of internal and external cracks caused by excessive heating and rapid removal of internal water from the product (Saath et al., 2010; Borém et al. 2013; Donadon et al., 2013). When drying damage affects essential structures of the embryo, such as cotyledons and/ or hypocotyl/radicle axis, delays in germination rate, seedling abnormalities and, in more severe cases, seed death can occur (Menezes et al. 2012; Wang et al., 2017).

In this study, the highest water removal rates (WRR) were observed with the increased drying air temperature (Figure 1), which may be one of the factors responsible for the immediate and latent damage found by the reduction of root protrusion 
Table 2. Root protrusion, root protrusion speed index, first count, and germination of non-stratified (NS) and cold stratified (CS) safflower seeds at five storage periods after initial drying at different air temperatures.

\begin{tabular}{|c|c|c|c|c|c|c|c|c|c|c|}
\hline \multirow{4}{*}{$\begin{array}{l}\text { Drying } \\
\text { temperature }\end{array}$} & \multicolumn{10}{|c|}{ Storage period (days) } \\
\hline & \multicolumn{2}{|c|}{0} & \multicolumn{2}{|c|}{60} & \multicolumn{2}{|c|}{120} & \multicolumn{2}{|c|}{180} & \multicolumn{2}{|c|}{240} \\
\hline & NS & $\mathrm{CS}$ & NS & $\mathrm{CS}$ & NS & CS & NS & CS & NS & $\mathrm{CS}$ \\
\hline & \multicolumn{10}{|c|}{ Root protrusion (\%) } \\
\hline $40^{\circ} \mathrm{C}$ & $9 \mathrm{~B}^{1}$ & $96 \mathrm{~A}$ & $32 \mathrm{~B}$ & $96 \mathrm{~A}$ & $36 \mathrm{~B}$ & $96 \mathrm{~A}$ & $80 \mathrm{~A}$ & $86 \mathrm{~A}$ & $75 \mathrm{~B}$ & $83 \mathrm{~A}$ \\
\hline $50^{\circ} \mathrm{C}$ & $7 \mathrm{~B}$ & $93 \mathrm{~A}$ & $29 \mathrm{~B}$ & $92 \mathrm{~A}$ & $33 \mathrm{~B}$ & $88 \mathrm{~A}$ & $77 \mathrm{~A}$ & $81 \mathrm{~A}$ & $73 \mathrm{~A}$ & $75 \mathrm{~A}$ \\
\hline $60^{\circ} \mathrm{C}$ & $5 \mathrm{~B}$ & $49 \mathrm{~A}$ & $23 \mathrm{~B}$ & $43 \mathrm{~A}$ & $17 \mathrm{~B}$ & $44 \mathrm{~A}$ & $36 \mathrm{~A}$ & $41 \mathrm{~A}$ & $39 \mathrm{~A}$ & $40 \mathrm{~A}$ \\
\hline \multirow[t]{2}{*}{$70^{\circ} \mathrm{C}$} & $4 \mathrm{~B}$ & $31 \mathrm{~A}$ & $4 \mathrm{~B}$ & $24 \mathrm{~A}$ & $3 \mathrm{~B}$ & $23 \mathrm{~A}$ & $4 \mathrm{~A}$ & $5 \mathrm{~A}$ & $3 \mathrm{~A}$ & $4 \mathrm{~A}$ \\
\hline & \multicolumn{10}{|c|}{ Root protrusion speed index (adimensional) } \\
\hline $40^{\circ} \mathrm{C}$ & $0.6 \mathrm{~B}$ & $45.7 \mathrm{~A}$ & $2.7 \mathrm{~B}$ & $45.3 \mathrm{~A}$ & $3.8 \mathrm{~B}$ & $46.9 \mathrm{~A}$ & $10.3 \mathrm{~B}$ & $37.1 \mathrm{~A}$ & $9.9 \mathrm{~B}$ & $34.3 \mathrm{~A}$ \\
\hline $50{ }^{\circ} \mathrm{C}$ & $0.5 \mathrm{~B}$ & $44.0 \mathrm{~A}$ & $2.2 \mathrm{~B}$ & $36.4 \mathrm{~A}$ & $3.1 \mathrm{~B}$ & $40.9 \mathrm{~A}$ & $9.0 \mathrm{~B}$ & $23.0 \mathrm{~A}$ & $8.3 \mathrm{~B}$ & $17.4 \mathrm{~A}$ \\
\hline $60{ }^{\circ} \mathrm{C}$ & $0.3 \mathrm{~B}$ & $19.1 \mathrm{~A}$ & $1.7 \mathrm{~B}$ & $11.0 \mathrm{~A}$ & $1.3 \mathrm{~B}$ & $14.8 \mathrm{~A}$ & $3.8 \mathrm{~B}$ & $7.4 \mathrm{~A}$ & $3.9 \mathrm{~B}$ & $6.3 \mathrm{~A}$ \\
\hline \multirow[t]{2}{*}{$70^{\circ} \mathrm{C}$} & $0.3 \mathrm{~B}$ & $8.8 \mathrm{~A}$ & $0.2 \mathrm{~B}$ & $7.8 \mathrm{~A}$ & $0.3 \mathrm{~B}$ & $6.6 \mathrm{~A}$ & $0.2 \mathrm{~A}$ & $0.8 \mathrm{~A}$ & $0.2 \mathrm{~A}$ & $0.5 \mathrm{~A}$ \\
\hline & \multicolumn{10}{|c|}{ First count $(\%)$} \\
\hline $40^{\circ} \mathrm{C}$ & $0 \mathrm{~B}$ & $88 \mathrm{~A}$ & $3 \mathrm{~B}$ & $77 \mathrm{~A}$ & $0 \mathrm{~B}$ & $71 \mathrm{~A}$ & $4 \mathrm{~B}$ & $64 \mathrm{~A}$ & $0 \mathrm{~B}$ & $62 \mathrm{~A}$ \\
\hline $50{ }^{\circ} \mathrm{C}$ & $0 \mathrm{~B}$ & $70 \mathrm{~A}$ & $0 \mathrm{~B}$ & $69 \mathrm{~A}$ & $0 \mathrm{~B}$ & $64 \mathrm{~A}$ & $4 \mathrm{~B}$ & $35 \mathrm{~A}$ & $0 \mathrm{~B}$ & $20 \mathrm{~A}$ \\
\hline $60^{\circ} \mathrm{C}$ & $0 \mathrm{~B}$ & $38 \mathrm{~A}$ & $1 \mathrm{~B}$ & $28 \mathrm{~A}$ & $0 \mathrm{~B}$ & $26 \mathrm{~A}$ & $2 \mathrm{~B}$ & $15 \mathrm{~A}$ & $0 \mathrm{~B}$ & $4 \mathrm{~A}$ \\
\hline \multirow[t]{2}{*}{$70^{\circ} \mathrm{C}$} & $0 \mathrm{~B}$ & $17 \mathrm{~A}$ & $0 \mathrm{~B}$ & $17 \mathrm{~A}$ & $0 \mathrm{~B}$ & $13 \mathrm{~A}$ & $0 \mathrm{~A}$ & $0 \mathrm{~A}$ & $0 \mathrm{~A}$ & $1 \mathrm{~A}$ \\
\hline & \multicolumn{10}{|c|}{ Germination (\%) } \\
\hline $40^{\circ} \mathrm{C}$ & $6 \mathrm{~B}$ & $90 \mathrm{~A}$ & $27 \mathrm{~B}$ & $87 \mathrm{~A}$ & $29 \mathrm{~B}$ & $78 \mathrm{~A}$ & 53B & $75 \mathrm{~A}$ & $56 \mathrm{~B}$ & $74 \mathrm{~A}$ \\
\hline $50{ }^{\circ} \mathrm{C}$ & $5 \mathrm{~B}$ & $82 \mathrm{~A}$ & $15 \mathrm{~B}$ & $72 \mathrm{~A}$ & $26 \mathrm{~B}$ & $71 \mathrm{~A}$ & $62 \mathrm{~A}$ & $58 \mathrm{~A}$ & $49 \mathrm{~A}$ & $48 \mathrm{~A}$ \\
\hline $60^{\circ} \mathrm{C}$ & $3 \mathrm{~B}$ & $43 \mathrm{~A}$ & 14B & $36 \mathrm{~A}$ & $10 \mathrm{~B}$ & $37 \mathrm{~A}$ & $21 \mathrm{~A}$ & $22 \mathrm{~A}$ & $13 \mathrm{~A}$ & $12 \mathrm{~A}$ \\
\hline $70^{\circ} \mathrm{C}$ & 3B & $19 \mathrm{~A}$ & $2 \mathrm{~B}$ & $17 \mathrm{~A}$ & $2 \mathrm{~B}$ & $19 \mathrm{~A}$ & $3 \mathrm{~A}$ & $3 \mathrm{~A}$ & $2 \mathrm{~A}$ & $2 \mathrm{~A}$ \\
\hline
\end{tabular}

${ }^{1}$ For each storage period, means followed by the same letter in the rows do not differ from each other by the Tukey test at $5 \%$ probability of error.

and RPSI of dry seeds at temperatures above $40{ }^{\circ} \mathrm{C}$, verified when cold stratification (non-dormant seeds) was used (Figures $3 \mathrm{C}$ and $3 \mathrm{D})$. On the other hand, without stratification, such damage to the germination process was only observed with the overcoming of dormancy during the storage period, and seeds dried at 40 and $50{ }^{\circ} \mathrm{C}$ did not differ regarding the behavior presented during 240 days (Figures 3A and 3B).

Similar results to non-stratified seeds (Figures $3 \mathrm{~A}$ and $3 \mathrm{~B}$ ) were found by Costa et al. (2012) with Crambe abyssinica seeds dried at $35,45,60,75$, and $90{ }^{\circ} \mathrm{C}$. These authors detected differences in physiological quality between lots due to drying damage only after the third month of storage when seed dormancy level was reduced.

No regression adjustment was observed for the first count of non-stratified seeds in relation to the storage, with values below 5\% at all periods for all drying conditions (Figure $4 \mathrm{~A})$. These results indicate a delay in the development of the essential structures of the embryo that determine seedling formation and may be associated with higher seed dormancy intensity in the first months of storage (Figures $3 \mathrm{~A}$ and $3 \mathrm{~B})$, together with a reduction in seed vigor due to the immediate and latent damage provided by the increased drying temperature (Figure 3D).

Unlike the results found for non-stratified seeds (Figure 4A), the use of cold stratification showed that an increase in drying temperature resulted in the immediate decrease of first seed count, especially in dryings at 60 and $70{ }^{\circ} \mathrm{C}$ (Figure 4B), confirming the loss of seed vigor due to a delay in seedling formation (Marcos-Filho, 2015). In general, seeds dried at $40{ }^{\circ} \mathrm{C}$ showed higher values at first count during storage, except at 60 and 120 days, when no difference was observed in relation to the experimental results obtained by seeds dried at $50{ }^{\circ} \mathrm{C}$. From 0 to 240 days, the estimated first count ranged from 86 to $59 \%, 71$ to $18 \%, 38$ to $6 \%$ and 19 to $0 \%$ for seeds dried at $40,50,60$ and $70{ }^{\circ} \mathrm{C}$, respectively.

Similar results to those found for stratified seeds of safflower (Figures 3C, 3D and 4B) were found in studies performed with seeds of Jatropha curcas (Ullmann et al., 2010), Vigna angularis 


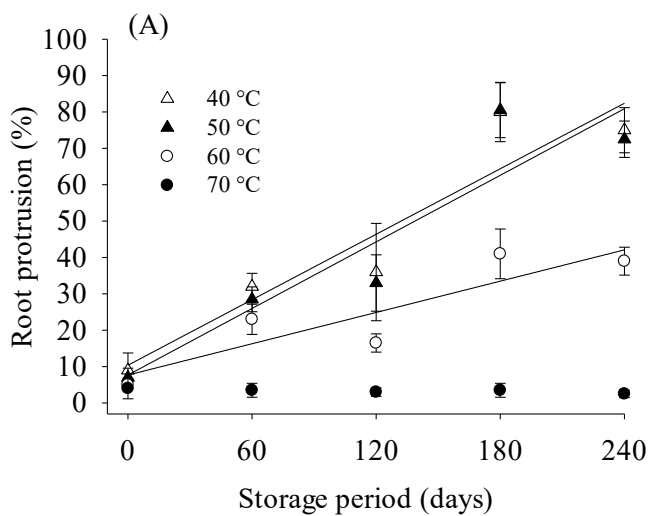

$\mathrm{RP}\left(40{ }^{\circ} \mathrm{C}\right)=10.4+0.3 \mathrm{x}, \mathrm{R}^{2}=0.89(\mathrm{p}=0.02)$

$R P\left(50{ }^{\circ} \mathrm{C}\right)=7.7+0.305 \mathrm{x}, \mathrm{R}^{2}=0.86(\mathrm{p}=0.02)$

$R P\left(60^{\circ} \mathrm{C}\right)=7.7+0.1433 \mathrm{x}, \mathrm{R}^{2}=0.80(\mathrm{p}=0.04)$ $\mathrm{RP}\left(70{ }^{\circ} \mathrm{C}\right)=3.3$ (no adjustment)

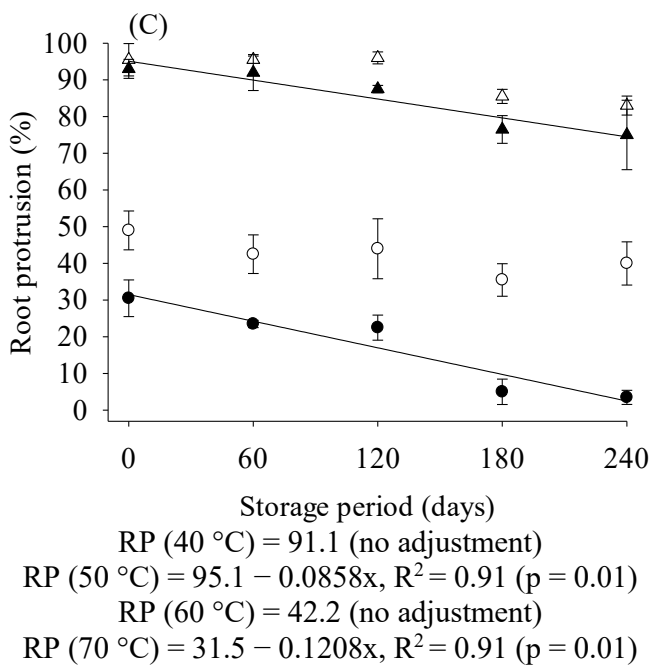

(B)

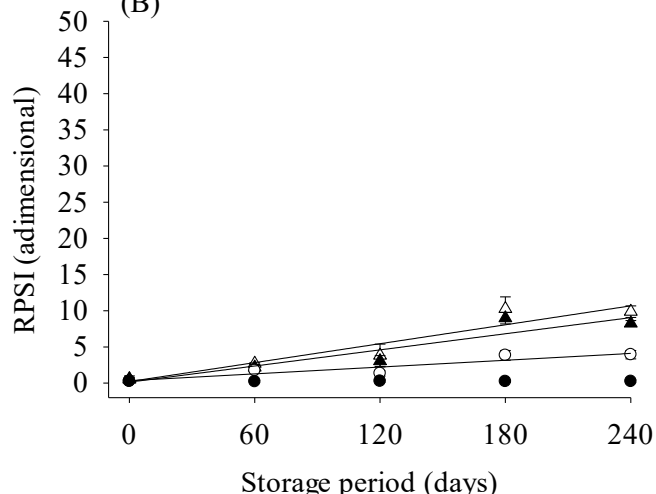

RPSI $\left(40^{\circ} \mathrm{C}\right)=0.2188+0.0436 \mathrm{x}, \mathrm{R}^{2}=0.89(\mathrm{p}=0.02)$

RPSI $\left(50^{\circ} \mathrm{C}\right)=0.1392+0.0371 \mathrm{x}, \mathrm{R}^{2}=0.86(\mathrm{p}=0.02)$

RPSI $\left(60^{\circ} \mathrm{C}\right)=0.3374+0.0157 \mathrm{x}, \mathrm{R}^{2}=0.86(\mathrm{p}=0.02)$

RPSI $\left(70^{\circ} \mathrm{C}\right)=0.2389$ (no adjustment)

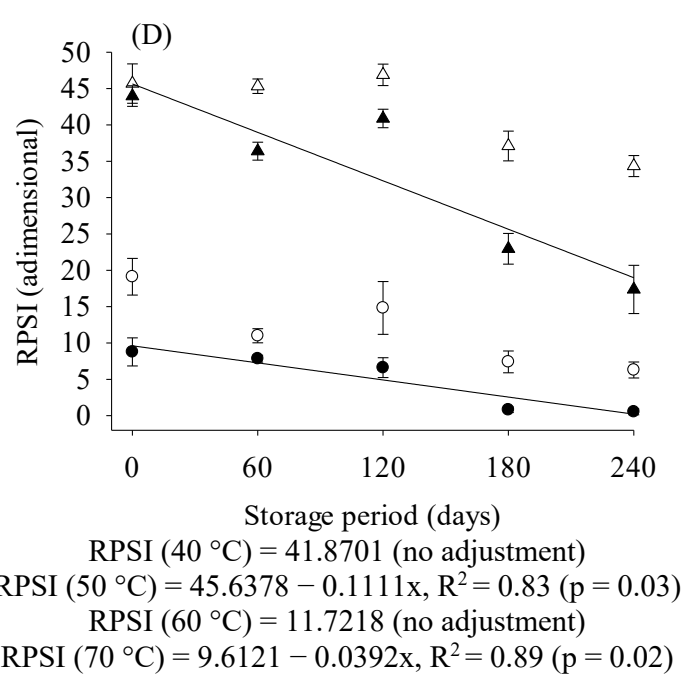

Figure 3. Root protrusion and root protrusion speed index (RPSI) of non-stratified (A and B) and cold stratified (C and D) safflower seeds at five storage periods after initial drying at different air temperatures. Bars represent the standard deviation of the mean.

(Resende et al., 2012), Sorghum bicolor (Ullmann et al., 2015), Arachis hypogaea (Sarath et al., 2016), Glycine max (HartmannFilho et al., 2016), Oryza sativa, and wild species of Oryza (Menezes et al., 2012; Wang et al., 2017; Timple and Hay, 2018), which showed a reduction in physiological potential when submitted to drying at temperatures above 40 to $50^{\circ} \mathrm{C}$.

A linear increase in the values of germination of nonstratified seeds (Figure 4C) was observed for lots dried at 40 and $50{ }^{\circ} \mathrm{C}$ from 0 to 240 days of storage, showing similar behavior, as observed for root protrusion and RPSI (Figures $3 \mathrm{~A}$ and $3 \mathrm{~B}$ ). However, an exception occurred only at 60 days, with a slightly higher experimental value for seeds dried at $40{ }^{\circ} \mathrm{C}$. Due to the severe damage caused during drying, evidenced by the natural and gradual overcoming of dormancy, seeds dried at $60^{\circ} \mathrm{C}$ and mainly at $70{ }^{\circ} \mathrm{C}$ presented lower germination than seeds dried at the lowest temperatures from 120 and 60 days, respectively, although no regression adjustment was observed for these drying conditions in relation to storage periods.

As observed for root protrusion, RPSI, and first count (Figures 3C, 3D and 4B), the use of cold stratification allowed understanding the immediate and latent effects of drying treatments on the real potential of seed germination. The increased air temperature led to the immediate decrease in germination, i.e., the capacity of seeds to originate normal seedlings, especially in dryings at 60 and $70{ }^{\circ} \mathrm{C}$. For these lots, results were lower than 46 and $20 \%$, respectively, from the first storage period (Figure 4D).

However, stratified seeds dried at $40{ }^{\circ} \mathrm{C}$ had estimated values between 90 and $81 \%$ until 120 days of storage, with 
$72 \%$ germination at the end of 240 days. These values decreased linearly from 82 to $50 \%$, between 0 and 240 days, for the seed lot dried at $50{ }^{\circ} \mathrm{C}$, confirming the lower physiological potential when compared to seeds dried at 40 ${ }^{\circ} \mathrm{C}$, although they have presented the same experimental value at 120 days (Figure 4D). When not stratified, seeds dried at 40 and $50{ }^{\circ} \mathrm{C}$ showed similar physiological behaviors over the evaluated period (Figures 3A, 3B, 4A and 4C). In this context, it is worth highlighting the importance of the knowledge on seed physiology, especially the aspects of the presence of dormancy, which can lead to the use of appropriate techniques, such as cold stratification, to obtain more reliable results on the viability and vigor of seeds as a function of treatments.
Furthermore, when using cold stratification it was found that storage periods under uncontrolled conditions led to a decrease in seed physiological quality, although less pronounced for seeds dried at $40{ }^{\circ} \mathrm{C}$ (Figures 3C, 3D, 4B and 4D). Excluding exceptional cases, seeds of most species cannot remain viable indefinitely. Therefore, according to Walters et al. (2010), these seeds may present, after a certain asymptomatic period, a sudden drop in physiological potential during storage due to a series of degenerative, irreversible, and progressive processes that act with a higher or lower intensity depending on the initial lot quality and storage conditions (e.g., seed moisture content and intergranular air temperature). Among the various physiological manifestations

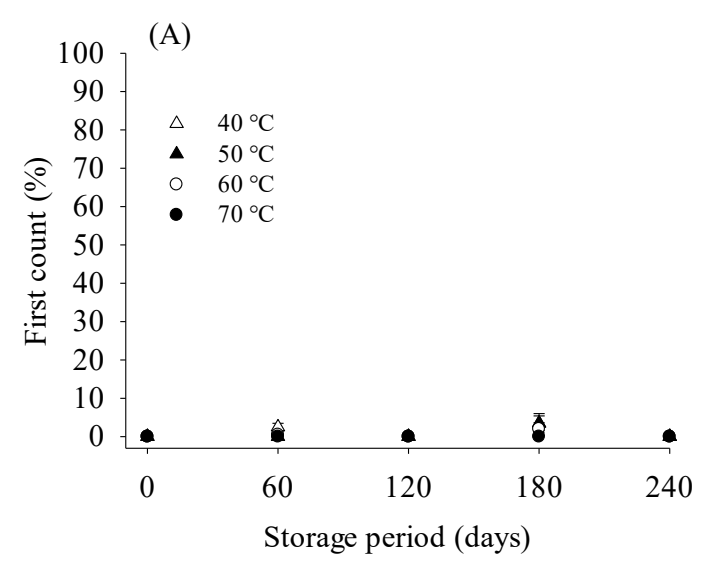

$\mathrm{FC}\left(40^{\circ} \mathrm{C}\right)=1.2$ (no adjustment)

$\mathrm{FC}\left(50^{\circ} \mathrm{C}\right)=0.7$ (no adjustment)

$\mathrm{FC}\left(60^{\circ} \mathrm{C}\right)=0.5$ (no adjustment)

$\mathrm{FC}\left(70^{\circ} \mathrm{C}\right)=0.0$ (no adjustment)

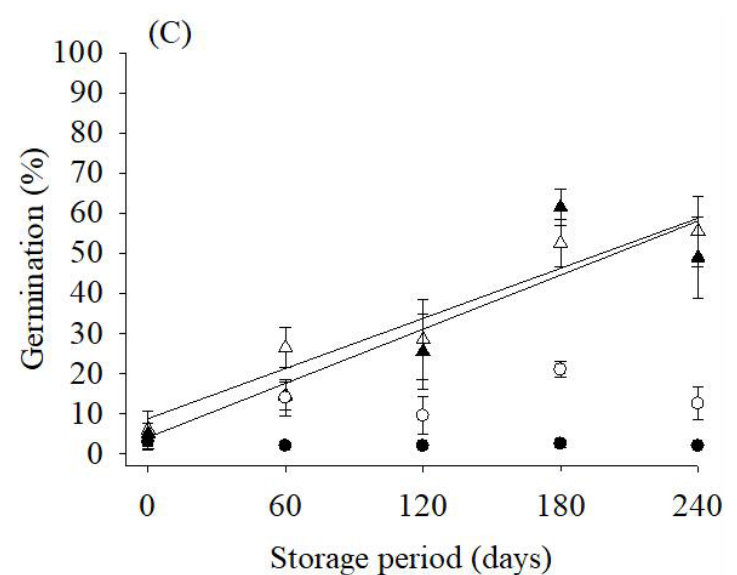

$\mathrm{G}\left(40{ }^{\circ} \mathrm{C}\right)=8.8+0.2083 \mathrm{x}, \mathrm{R}^{2}=0.93(\mathrm{p}<0.01)$

$\mathrm{G}\left(50^{\circ} \mathrm{C}\right)=4.1+0.225 \mathrm{x}, \mathrm{R}^{2}=0.82(\mathrm{p}=0.04)$

$\mathrm{G}\left(60^{\circ} \mathrm{C}\right)=12.1$ (no adjustment)

$\mathrm{G}\left(70^{\circ} \mathrm{C}\right)=2.3$ (no adjustment)

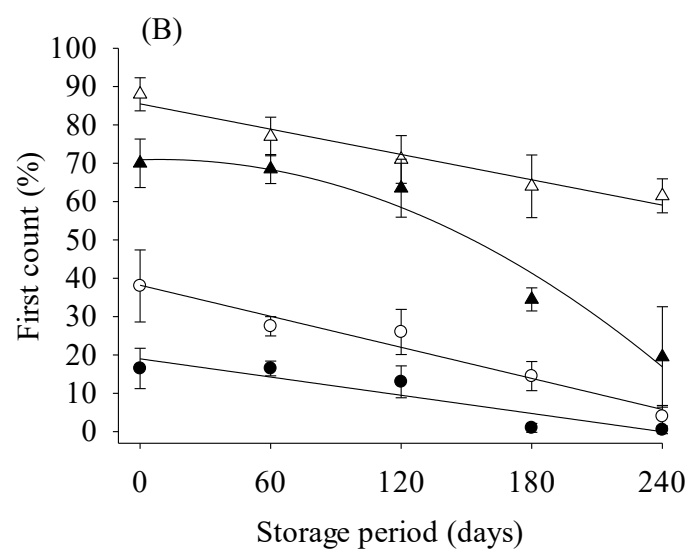

$\mathrm{FC}\left(40{ }^{\circ} \mathrm{C}\right)=85.5-0.11 \mathrm{x}, \mathrm{R}^{2}=0.96(\mathrm{p}<0.01)$

$\mathrm{FC}\left(50{ }^{\circ} \mathrm{C}\right)=70.9143+0.0179 \mathrm{x}-0.001 \mathrm{x}^{2}, \mathrm{R}^{2}=0.96(\mathrm{p}=0.04)$

$\mathrm{FC}\left(60^{\circ} \mathrm{C}\right)=38.2-0.135 \mathrm{x}, \mathrm{R}^{2}=0.96(\mathrm{p}<0.01)$

$\mathrm{FC}\left(70{ }^{\circ} \mathrm{C}\right)=19.0-0.0792 \mathrm{x}, \mathrm{R}^{2}=0.86(\mathrm{p}=0.02)$

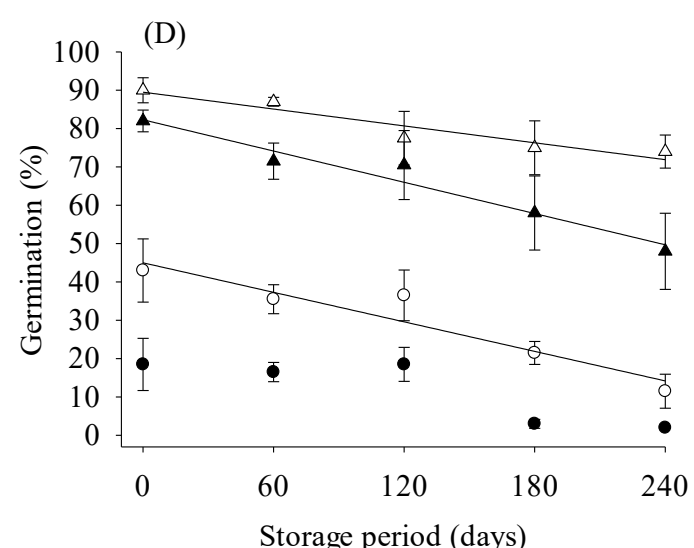

$$
\begin{gathered}
\mathrm{G}\left(40{ }^{\circ} \mathrm{C}\right)=89.5-0.0733 \mathrm{x}, \mathrm{R}^{2}=0.91(\mathrm{p}=0.01) \\
\mathrm{G}\left(50^{\circ} \mathrm{C}\right)=82.3-0.1358 \mathrm{x}, \mathrm{R}^{2}=0.96(\mathrm{p}<0.01) \\
\mathrm{G}\left(60^{\circ} \mathrm{C}\right)=45.0-0.1283 \mathrm{x}, \mathrm{R}^{2}=0.91(\mathrm{p}=0.01) \\
\mathrm{G}\left(70{ }^{\circ} \mathrm{C}\right)=11.7 \text { (no adjustment) }
\end{gathered}
$$

Figure 4. First count and germination of non-stratified (A and C) and cold stratified (B and D) safflower seeds at five storage periods after initial drying at different air temperatures. Bars represent the standard deviation of the mean. 
of deterioration in stored seeds, stratified seeds (Figures 3C, $3 \mathrm{D}, 4 \mathrm{~B}$ and 4D) showed a reduction in the percentage and speed of root protrusion, first count, and germination.

\section{Conclusions}

The increased drying air temperature leads to higher water removal rates, promoting immediate and latent damage to seed physiological quality, evidenced by the reduction in the percentage and speed of root protrusion, first count, and germination, especially at 60 and $70{ }^{\circ} \mathrm{C}$. The drying temperature should not exceed $40{ }^{\circ} \mathrm{C}$ for the maintenance of germination and vigor of safflower seeds up to 240 days of storage, especially when they have moisture contents close to or higher than $25.8 \%$ at the drying moment.

\section{Acknowledgments}

To UFGD. To CAPES, CNPq and Fundect for financial support of this research. To prof. dr. Luiz Carlos Ferreira de Souza (UFGD) for kindly providing the seeds used in this study. To the editor and anonymous reviewers of the Journal of Seed Science for the valuable suggestions and corrections proposed for improving this study.

\section{References}

AL SURMI, N.Y.; EL DENGAWY, R.A.H.; KHALIFA, A.H. Chemical and nutritional aspects of some saffower seed varieties. Journal of Food Processing and Technology, v.7, n.5, p.1-5, 2016. https://www.omicsonline.org/open-access/chemical-and-nutritionalaspects-of-some-safflower-seed-varieties-2157-7110-1000585. php?aid $=73864$

BARATI, M.; ZARE, D.; ZOMORODIAN, A. Moisture sorption isotherms and thermodynamic properties of safflower seed using empirical and neural network models. Journal of Food Measurement and Characterization, v.10, n.2, p.236-246, 2016. https://link. springer.com/article/10.1007/s11694-015-9298-4

BARROZO, M.A.S.; MUJUMDAR, A.; FREIRE, J.T. Air-drying of seeds: a review. Drying Technology, v.32, n.10, p.1127-1141, 2014. http://www.tandfonline.com/doi/abs/10.1080/07373937.2014.915220

BORÉM, F.M.; OLIVEIRA, P.D.; ISQUIERDO, E.P.; GIOMO, G.S.; SAATH, R.; CARDOSO, R.A. Microscopia eletrônica de varredura de grãos de café submetidos a diferentes formas de processamento e secagem. Coffee Science, v.8, n.2, p.227-237, 2013. http://www.coffeescience.ufla. br/index.php/Coffeescience/article/view/420/pdf_150

BRASIL. Ministério da Agricultura, Pecuária e Abastecimento.
Regras para análise de sementes. Ministério da Agricultura, Pecuária e Abastecimento. Secretaria de Defesa Agropecuária. Brasília: MAPA/ACS, 2009. 395p. http://www.agricultura.gov.br/assuntos/ insumos-agropecuarios/arquivos-publicacoes-insumos/2946 regras_analise_sementes.pdf

CORRÊA,P.C.;MACHADO,P.F.;ANDRADE,E.T.Cinéticadesecagem e qualidade de grãos de milho-pipoca. Ciência e Agrotecnologia, v.25, n.1, p.134-142, 2001. https://www.agencia.cnptia.embrapa.br/Repositorio/ cineticasecagem_000ffh585q802wx5eo05vmaqk8upbm8a.pdf

COSTA, L.M.; RESENDE, O.; GONÇALVES, D.N.; MARÇAL, K.A.F.; SALES, J.F. Storage of crambe fruit subjected to different drying conditions. African Journal of Agricultural Research, v.7, n.47, p.6274-6280, 2012. http://www.academicjournals.org/app/ webroot/article/article1380974307_Costa\%20et\%20al.pdf

DESAI, B.B. Seeds handbook. Biology, production, processing, and storage. 2.ed. New York: Marcel Dekker, Inc., 2004. 800p.

DOLATABADIAN, A.; SANAVY, S.A.M.M. Effect of the ascorbic acid, pyridoxine and hydrogen peroxide treatments on germination, catalase activity, protein and malondialdehyde content of three oil seeds. Notulae Botanicae Horti Agrobotanici, v.36, n.2, p.61-66, 2008. http://www.notulaebotanicae.ro/index.php/nbha/article/view/70/53

DONADON, J.R.; RESENDE, O.; TEIXEIRA, S.P.; SANTOS, J.M.; MORO, F.V. Effect of hot air drying on ultrastructure of crambe seeds. Drying Technology, v.31, n.3, p.269-276, 2013. http:// www.tandfonline.com/doi/abs/10.1080/07373937.2012.724490

EMONGOR, V. Safflower (Carthamus tinctorius L.) the underutilized and neglected crop: a review. Asian Journal of Plant Sciences, v.9, n.6, p.299-306, 2010. https://scialert.net/abstract/?doi=ajps.2010.299.306

FERREIRA, D.F. Sisvar: a computer statistical analysis system. Ciência e Agrotecnologia, v.35, n.6, p.1039-1042, 2011. http://www. scielo.br/pdf/cagro/v35n6/a01v35n6.pdf

FLEMMER, A.C.; FRANCHINI, M.C.; LINDSTRÖM, L.I. Description of safflower (Carthamus tinctorius) phenological growth stages according to the extended BBCH scale. Annals of Applied Biology, v.166, n.2, p.331-339, 2015. http://onlinelibrary.wiley.com/ doi/10.1111/aab.12186/pdf

FRANCHINI, M.C.; FLEMMER, A.C.; LINDSTRÖM, L.I.; DAVID, M.A.; FERNANDEZ, P.A. Fruit development of two high oleic safflower (Carthamus tinctorius L.) cultivars. ФYTON - Revista Internacional de Botánica Experimental, v.83, n.2, p.379-388, 2014. http://www.scielo.org.ar/pdf/phyton/v83n2/v83n2a21.pdf

HARTMANN-FILHO, C.P.; GONELI, A.L.D.; MASETTO, T.E.; MARTINS, E.A.S.; OBA, G.C. Physiological quality of second crop soybean seeds after drying and storage. African Journal of Agricultural Research, v.11, n.35, p.3273-3280, 2016. http:// www.academicjournals.org/journal/AJAR/article-full-textpdf/4C7EEBA60249

KENENI, Y.G.; HVOSLEF-EIDE, A.K.; MARCHETTI, J.M. Mathematical modelling of the drying of Jatropha curcas L. seeds. Industrial Crops and Products, v.132, p.12-20, 2019. https://www. sciencedirect.com/science/article/pii/S0926669019301049

KHALID, N.; KHAN, R.S.; HUSSAIN, M.I.; FAROOQ, M.; 
AHMAD, A.; AHMED, I. A comprehensive characterization of safflower oil for its potential applications as a bioactive food ingredient - a review. Trends in Food Science and Technology, v.66, p.176-186, 2017. https://www.sciencedirect.com/science/article/abs/ pii/S0924224417301607

LAURSEN, R.; MOURI, C. Decomposition and analysis of carthamin in safflower-dyed textiles. E-Preservation Science, v.10, p.35-37, 2013. http://www.morana-rtd.com/epreservationscience/2013/Laursen-16-12-2012.pdf

MAGUIRE, J.D. Speed of germination-aid in selection and evaluation for seedling emergence and vigor. Crop Science, v.2, n.1, p.176-177, 1962.

MARCOS-FILHO, J. Seed vigor testing: an overview of the past, present and future perspective. Scientia Agricola, v.72, n.4, p.363-374, 2015. http://www.scielo.br/pdf/sa/v72n4/0103-9016sa-72-4-0363.pdf

MAYERHOFER, M.; MAYERHOFER, R.; TOPINKA, D.; CHRISTIANSON, J.; GOOD, A.G. Introgression potential between safflower (Carthamus tinctorius) and wild relatives of the genus Carthamus. BMC Plant Biology, v.11, n.47, p.1-10, 2011. https:// bmcplantbiol.biomedcentral.com/articles/10.1186/1471-2229-11-47

MENEZES, N.L.; CICERO, S.M.; VILLELA, F.A.; BORTOLOTTO, R.P. Using X-Rays to evaluate fissures in rice seeds dried artificially. Revista Brasileira de Sementes, v.34, n.1, p.70-77, 2012. http:// www.scielo.br/pdf/rbs/v34n1/a09v34n1.pdf

OBA, G.C.; GONELI, A.L.D.; MASETTO, T.E.; HARTMANNFILHO, C.P.; PATRICIO, V.S.; SARATH, K.L.L. Dormancy of safflower seeds: effect of storage and cold stratification. Journal of Seed Science, v.39, n.4, p.433-439, 2017. http://www.scielo.br/pdf/ jss/v39n4/2317-1545-jss-39-04-433.pdf

OLIVEIRA, C.V.K.; SANTOS, R.F.; SIQUEIRA, J.A.C.; BARICCATTI, R.A.; LENZ, N.B.G.; CRUZ, G.S.; TOKURA, L.K.; KLAJN, F.F. Chemical characterization of oil and biodiesel from four safflower genotypes. Industrial Crops and Products, v.123, p.192-196, 2018. https://www.sciencedirect.com/science/article/pii/ S0926669018305466

RESENDE, O.; ALMEIDA, D.P.; COSTA, L.M.; MENDES, U.C.; SALES, J.F. Adzuki beans (Vigna angularis) seed quality under several drying conditions. Ciência e Tecnologia de Alimentos, v.32, n.1, p.151155, 2012. http://www.scielo.br/pdf/cta/v32n1/aop_cta_5007.pdf

SAATH, R.; BORÉM, F.M.; ALVES, E.; TAVEIRA，J.H.S.; MEDICE, R.; CORADI, P.C. Microscopia eletrônica de varredura do endosperma de café (Coffea arabica L.) durante o processo de secagem. Ciência e Agrotecnologia, v.34, n.1, p.196-203, 2010. http://www.scielo.br/pdf/cagro/v34n1/25.pdf
SARATH, K.L.L.; GONELI, A.L.D.; HARTMANN-FILHO, C.P.; MASETTO, T.E.; OBA, G.C. Physiological potential of peanut seeds submitted to drying and storage. Journal of Seed Science, v.38, n.3, p.233-240, 2016. http://www.scielo.br/pdf/jss/v38n3/2317-1545-jssv38n3165008.pdf

SCARIOT, M.A.; RADÜNZ, L.L.; DIONELLO, R.G.; TONI, J.R.; MOSSI, A.J.; REICHERT JÚNIOR, F.W. Quality of wheat grains harvested with different moisture contents and storage in hermetic and conventional system. Journal of Stored Products Research, v.75, p.29-34, 2018. https://www.sciencedirect.com/science/article/abs/ pii/S0022474X17302680

SOUZA, L.C.F.; LUIS, A.J.; PILETTI, L.M.M.S. Características agronômicas do milho em função da cultura antecessora em sistema de plantio direto. Revista Brasileira de Milho e Sorgo, v.15, n.2, p.272-280, 2016. http://rbms.cnpms.embrapa.br/index.php/ojs/ article/view/640/pdf_464

TIMPLE, S.E.; HAY, F.R. High-temperature drying of seeds of wild Oryza species intended for long-term storage. Seed Science and Technology, v.46, n.1, p.107-112, 2018. https://www.ingentaconnect. com/content/ista/sst/2018/00000046/00000001/art00010

ULLMANN, R.; RESENDE, O.; CHAVES, T.H.; OLIVEIRA, D.E.C.; COSTA, L.M. Qualidade fisiológica das sementes de sorgo sacarino submetidas à secagem em diferentes condições de ar. Revista Brasileira de Engenharia Agrícola e Ambiental, v.19, n.1, p.64-69, 2015. http://www.agriambi.com.br/revista/v19n01/v19n01a11.pdf

ULLMANN, R.; RESENDE, O.; SALES, J.F.; CHAVES, T.H. Qualidade das sementes de pinhão-manso submetidas à secagem artificial. Revista Ciência Agronômica, v.41, n.3, p.442-447, 2010. http://ccarevista.ufc.br/seer/index.php/ccarevista/article/view/911/463

WALTERS, C.; BALlESTEROS, D.; VERTUCCI, V.A. Structural mechanics of seed deterioration: standing the test of time. Plant Science, v.179, n.6, p.565-573, 2010. https://www.sciencedirect. com/science/article/pii/S0168945210001846

WANG, P.; LI, D.; WANG, L.J. Drying damage on physiological properties of rice seed associated with ultrastructure changes. International Journal of Food Engineering, v.13, n.12, p.1-12, 2017. https://www.degruyter.com/view/j/ijfe.2017.13.issue-12/ijfe-20170096/ijfe-2017-0096.xml

ZHOU, X.; TANG, L.; XU, Y.; ZHOU, G.; WANG, Z. Towards a better understanding of medicinal uses of Carthamus tinctorius L. in traditional chinese medicine: a phytochemical and pharmacological review. Journal of Ethnopharmacology, v.151, n.1, p.27-43, 2014. http://www.sciencedirect.com/science/article/pii/ S0378874113007757 